\title{
Kontribusi Naungan Pohon terhadap Kepadatan Cacing Tanah
}

\section{The Effect of Tree Shading to Earthworms Density}

\author{
SRI DWIASTUTI, SAJIDAN \\ Program Studi Pendidikan Biologi FKIP Universitas Sebelas Maret \\ Jl. Ir. Sutami No. 36A Kentingan Surakarta \\ *email: dwiastuti54@gmail.com
}

Manuscript received: 3 Juli 2014 Revision accepted: 5 Agustus 2014

\begin{abstract}
This research aims at exploring the contribution of the shade of treetowards the density of earthworms. The convertionof forest into a farmland causeda change in the shade of tree from a closed into an open ecosystem that was predicted to be followed by the decrease of earthworms density. The kinds of land thatis used for research are forest, complex agroforestry, simple agroforestry, teak monoculture, teak-accacia polyculture, and peanut crops. The data were analyzed quantitatively using statistical methods by SPSS 0.16 . The results show that the wide oftree shade contributes to the density of earthworms on rainy season as much as $71.5 \%$ and also contributes to the density of earthworms on dry season as much as $52.2 \%$. From the results, it can be concluded that the shade of tree has a strong role towards the density of earthworms.
\end{abstract}

Keywords: shade of tree, earthworms

\section{LATAR BELAKANG}

Konversi hutan menjadi lahan pertanian merupakan bentuk degradasi dan kerusakan lahan dengan adanya penurunan naungan pohon sebagai satu ekosistem lingkungan. Sistem manajemen penggunaan lahan dapat mempengaruhi emisi $\mathrm{CO}_{2}$ yang berkaitan erat dengan produksi pertanian (Flessa et al. 2002; Dalgaard et al. 2003). Berbagai penggunaan lahan dengan variasi tanaman budidaya yang ada saat ini memiliki sumbangan yang berbeda-beda terhadap kepadatan cacing tanah.

Cacing tanah merupakan makrofauna yang keberadaannya di dalam tanah sangat dipengaruhi oleh tutupan lahan. Naungan pohon akan mempertahankan iklim mikro terutama kelembaban udara (Hairiah.K. et.al 2004) yang mendukung kehidupan cacing tanah. Populasinya dipengaruhi oleh makanan yang tersedia pada ekosistem tersebut, yang berasal dari seresah tanaman dan berbagai sisa organik dari organisme lain, serta kondisi iklim mikro. Cacing tanah dapat merespon perubahan lingkungan dengan cara bermigrasi ke tempat lain (Sugiyarto, 2003).Kemudian Hale et al.,(2006) menyatakan bahwa perubahan struktur kimia tanah dan dinamika hara akan mempengaruhi invasi cacing tanah. Oleh karena itu cacing tanah dapat dijadikan bioindikator produktivitas dan kesinambungan fungsi tanah, sehingga eksistensi dan peran cacing tanah dapat digunakan sebagai informasi awal dalam rangka meningkatkan kesuburan tanah khususnya dilokasi penelitian yaitu tanah marginal berbahan induk kapur yang miskin hara.

Cacing tanah yang mengalami penurunan populasi disebabkan oleh penurunan atau hilangnya sejumlah spesies tumbuhan, penurunan produksi serasah, perubahan sifat biologis, fisik dan kimia tanah, dan perubahan iklim mikro ke arah yang kurang menguntungkan (Nuril et al., 1999).Namun demikian dikatakan oleh Foth (1994) bahwa cacing tanah tidak menyukai kondisi jenuh air dan peka radiasi sinar ultra violet. Cacing tanah tidak mampu makan seresah segar yang baru jatuh dari pohon. Seresah tersebut membutuhkan periode tertentu untuk lapuk atau terurai sampai cacing tanah mampu memakannya (Edward \& Lofty,1977).Cacing tanah akan meremah-remah substansi nabati yang mati, kemudian bahan tersebut akan dikeluarkan dalam bentuk kotoran yang bercampur dengan tanah (Rahmawaty, 2004).Lebih lanjut bahan organik tanah sangat berperan dalam memperbaiki sifat fisik tanah, meningkatkan aktivitas biologi tanah dan meningkatkan ketersediaan hara bagi tanaman (Suin, 1997).

\section{METODE}

Pengambilan sampel cacing tanah menggunakan prosedur monolit yaitu cacing diambil pada tanah berukuran $25 \mathrm{~cm} \times 25 \mathrm{~cm} \times 30 \mathrm{~cm}$, diambil dari 4 lapisan kedalaman yaitu lapisan permukaan, $0-10 \mathrm{~cm}, 10-20 \mathrm{~cm}$, dan 20-30 $\mathrm{cm}$.yang dilakukan dengan metode handsorting. Untuk mencari kepadatan cacing tanah dengan cara menghitung jumlah spesies/ populasi (ekor/m²). Menghitung kepadatan (density, ekor $/ \mathrm{m}^{2}$ ) dengan mengkonversi dari hitungan metode monolit dengan $\mathrm{cm}^{2}$ ke satuan $\mathrm{m}^{2}$ yaitu 10.000/625x jumlah cacing.

Pengukuran luas naungan pohon dilakukan dengan menggunakan meteran, dimana setiap pohon diukur 
sebanyak 4 kali pengukuran diameter dengan batang utama pohon sebagai titik tengahnya. Untuk pengukuran iklim mikro dilakukan setiap pagi dan siang hari seminggu dua kali. Iklim Mikro yang diamati meliputi suhu tanah, kelembaban udara, sertasuhuudara. Pengukuran suhu tanah dengan menggunakan $\mathrm{pH}$ meter dan suhu udara serta kelembaban udara dengan termohigrometer.

Data penelitian dianalisis secara kuantitatif menggunakan metode statistik dengan alat bantu SPSS 0.16 dengan urutan sebagai berikut: Untuk mengetahui pengaruh Sistem Penggunaan Lahan terhadap faktor lingkungan yang memungkinkan adanya perbedaan kepadatan cacing tanah perlu diuji dengan analysis of variance (ANOVA). Dari hasil uji ANOVA dicari yang signifikan kemudian diuji lanjut dengan uji DUNCAN. Keeratan hubungan antar variabel diuji dengan analisis KORELASI. Bila hubungan dari korelasi tersebut sangat nyata atau nyata dilajutkan dengan uji REGRESI untuk mengetahui bentuk hubungannya.

\section{HASIL DAN PEMBAHASAN}

Adanya berbagai naungan pohon pada suatu lahan akan menciptakan iklim mikro yang memberikan kontribusi pada kepadatan cacing tanah. Kondisi lahan hutan, cacing tanah cenderung kehilangan biomassa dibandingkan kepadatannya. hal ini ditunjukkan bahwa biomassa cacng tanah dihutan sejumlah $11,03 \mathrm{gram} / \mathrm{m}^{2}$ dan di lahan agroforestri cenderung lebih besar yaitu $40,77 \mathrm{gram} / \mathrm{m}^{2}$, hal ini disebabkan hutan cenderung lebih lembab sehingga lebih mengarah ke reproduksinya untuk perkembang biakan cacing; seperti yang dikatakan oleh Hubbard, Jordan dan Syecker (1999) bahwa biomasa cacing akan meningkat kalau cacing berada pada lahan yang membutuhkan peengelolaan petani dengan pemupukan. Lebih lanjut Ansyori (2004) menjelaskan bahwa kepadatan dan distribusi cacing tanah tidak hanya berhubungan dengan pengelolaan lahan tetapi juga faktor tanah dan iklim.

Lingkungan yang terganggu atau terdegradasi pada umumnya memiliki fauna tanah yang mengalami penurunan komposisi maupun populasi yang disebabkan oleh penurunan atau hilangnya sejumlah spesies tumbuhan, penurunan kekayaan deposit seresah, perubahan sifat biologis, fisik dan kimia tanah dan perubahan iklim mikro (Erniwati, 2008; Nuril et al., 1999).

\section{a. Pengaruh Sistem Penggunaan Lahan terhadap Naungan Pohon,}

Penggunaan lahan berpengaruh sangat nyata $(p<0,01)$ terhadap luas naungan pohon (Gambar 1), penggunaan lahan hutan dan lahan kacang tanah berbeda nyata dengan penggunaan lahan lain. Adanya naungan pohon akan mempengaruhi kondisi iklim mikro secara nyata antara lain kelembaban tanah dan kelembaban udara $(\mathrm{p}<0,00)$, suhu tanah dan suhu udara $(\mathrm{p}<0,01)$, kepadatan cacing tanah musim hujan $(\mathrm{p}<0,05)$, dan kepadatan cacing tanah musim kemarau $(\mathrm{p}<0,01)$, intensitas cahaya $(\mathrm{p}<0,01)$. Hal ini membuktikan bahwa peran lingkungan sangat penting dalam menentukan keberlanjutan suatu ekosistem.

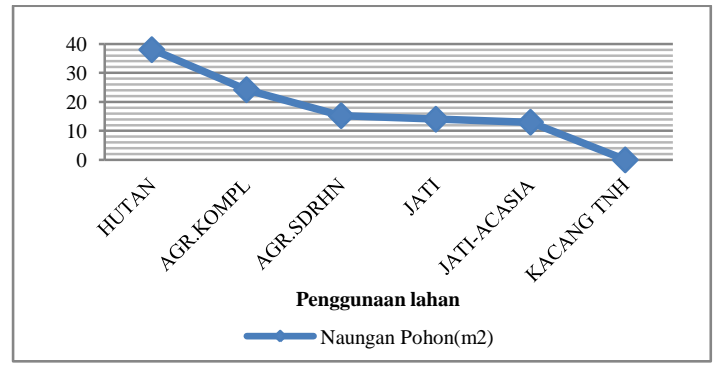

Gambar 1. Luas naungan pohon pada berbagai penggunaan lahan.

Ekosistem hutan merupakan ekosistem yang sangat kompleks didalamnya tidak hanya pohon yang tinggi dengan naungan yang luas tapi juga ditumbuhi semak, tumbuhan bawah, mikro dan makrofauna yang saling berinteraksi satu sama lain yang secara keseluruhan membentuk persekutuan hidup. Dikatakan oleh Van Noorwijk et al., 2001 dalam Dewi 2007 bahwa pelayanan lingkungan yang dapat diberikan oleh ekosistem hutan bagi kesejahteraan manusia merupakan interaksi antara fungsi tanah dan bagian diatas tanah.

Naungan pada suatu pohon berfungsi sebagai intersepsi cahaya dan air yang jatuh pada permukaan tanah. Luas naungan pada tiap pohon berbeda pada berbagai penggunaan lahan, hal ini terjadi karena setiap pohon memiliki morfologi cabang dan daun yang berbedabeda. Selain itu, umur pohon dan iklim jugamempengaruhi seberapa besar luas tajuk yang menutupi permukaan tanah. Konversi lahan hutan menjadi lahan pertanian selain mengurangi jumlah vegetasi juga akan meningkatkan limpasan permukaan (Widianto et al., 2004). Naungan pohon dapat memberikan masukan seresah yang jatuh ditanahdan dapat menciptakan kelembaban tanah sebagai iklim mikro dan mampu meningkatkan kandungan bahan organik tanah.

Perubahan lahan hutan menjadi lahan pertanian disebabkan karena adanya pengurangan vegetasi dan luas naungan pohon. Permukaan tanah yang tanpa naungan pohon lebih banyak menyerap panas matahari dan juga lebih banyak memantulkannya, sehingga menyebabkan temperatur permukaan dan suhu lingkungan naik. Adanya naungan pohon menyebabkan tempat teduh dan terjadi pertukaran udara sehingga udara lebih dingin. Naungan pohon juga memberikan dampak pada meningkatnya kelembaban tanah karena kurangnya radiasi cahaya matahari.

\section{b. Pengaruh penggunaan lahan terhadap kepadatan cacing tanah}

Perbedaan penggunaan lahan mempunyai pengaruh yang nyata $(\mathrm{p}<0,05)$ terhadap kepadatan cacing tanah musim hujan. Adanya kepadatan pada musim hujan tersebut bisa dipahami akan menambah faktor kelembaban bagi iklim mikro yang menguntungkan cacing dalam bereproduksi sehingga kepadatannya meningkat. Hal ini nampak adanya perbedaan kepadatan cacing tanah pada lahan hutan 
(1579 ekor) dan tanaman semusim kacang tanah yang merupakan lahan terbuka (629 ekor).Dikatakan oleh Baker (1998) bahwa kepadatan cacing tanah dipengaruhi oleh sistem penggunaan lahan. Hal ini bisa kita lihat bahwa cacing tanah dibawah naungan pohon (hutan) memiliki kepadatan yang tinggi karena naungan pohon tersebut akan mengurangi evaporasi dan menjaga suhu tanah.

Perbedaan kepadatan cacing musim hujan paling menyolok terdapat pada penggunaan lahan hutandan pada penggunaan lahan monokultur jati (tabel 1), hal ini bisa difahami bahwa hutan memilki banyak naungan dan jenis pohon yang menghasilkan kualitas guguran seresah yang tinggi. Kualitas seresah dimaksud adalah seresah yang cepat mengalami dekomposisi. Kondisi tersebut mendukung cacing untuk berkembang biak lebih cepat, sedang monokultur jati menghasilkan satu jenis pohon dengan guguran seresah yang kurang berkualitas sehingga daun-daun jati tersebut kurang disukai cacing karena mengandung lignin tinggi dan pada waktu musim kemarau pohon jati meranggas banyak menggugurkan daunnya.

Tabel 1. Luas naungan pohon, jumlah cacing tanah musim hujan dan kemarau

\begin{tabular}{cccc}
\hline $\begin{array}{c}\text { Penggunaan } \\
\text { lahan }\end{array}$ & $\begin{array}{c}\text { Luas nau- } \\
\text { ngan } \\
\text { pohon } \\
(\mathrm{m} 2)\end{array}$ & $\begin{array}{c}\text { Kepadatan } \\
\text { Cacing } \\
\text { musim } \\
\text { Hujan } \\
\text { (ekor/m2) }\end{array}$ & $\begin{array}{c}\text { Kepadatan } \\
\text { Cacing Musim } \\
\text { Kemarau } \\
\text { (ekor/m2) }\end{array}$ \\
\hline $\begin{array}{c}\text { Hutan } \\
\text { Agroforestri } \\
\text { kompleks }\end{array}$ & 38,03 & 1579 & 144 \\
Agroforestri & 24,21 & 773 & 368 \\
$\begin{array}{c}\text { Sederhana } \\
\text { Monokultur Jati } \\
\text { Jati-Acasia }\end{array}$ & 15,25 & 197 & 32 \\
$\begin{array}{c}\text { Tan.semusim } \\
\text { kacang tanah }\end{array}$ & 13,02 & 101 & 0 \\
\hline
\end{tabular}

Ada pengaruh yang sangat nyata $(\mathrm{p}<0,01)$ antara penggunaan lahan terhadap kepadatan cacing tanah musim kemarau. Musim hujan dan musim kemarau merupakan perbedaan musim yang sangat menyolok dan hal ini juga diikuti oleh perbedaan kepadatan cacing tanah. Pada musim kemarau banyak seresah digugurkan daripada musim hujan. Cacing tanah umumnya memakan serasah daun dan juga materi tumbuhan lainnya yang telah mati, kemudian dicerna dan dikeluarkan berupa kotoran. Kemampuan hewan ini dalam mengkonsumsi serasah sebagai maka-nannya bergantung pada ketersediaan jenis serasah yang disukainya, disamping itu juga ditentukan oleh kandungan karbon dan nitrogen serasah (Sulistiyanto, Y. et al. 2005). Pada musim kemarau jumlah cacing tanah tertinggi terdapat pada sistem penggu-naan lahan tanaman semusim kacang tanah (496 ekor $\left./ \mathrm{m}^{2}\right)$ sedang pada penggunaan lahan jati dan polikultur jati-acasia tidak ditemukan cacing sama sekali. Pada lahan kacang tanah media tanam selalu diberi pupuk organik dan disiram sehingga kondisi selalu basah maka mendukung untuk perkembang biakan cacing sedang pada lahan lainnya dibiarkan begitu saja sehingga media tanah disekitarnya tetap kering. Cacing akan bisa menyesuaikan diri pada kondisi lapar daripada faktor kekeringan.

Lebih lanjut Suprayogo et al. (2003) mengatakan bahwa pepohonan, tanaman semusim dan gulma dalam penggunaan lahan agroforestri memberikan masukan bahan organik melalui daun, ranting dan cabang yang telah gugur di atas permukaan tanah dalam bentuk seresah (litter) yang merupakan makanan cacing tanah. Kemudian dikatakan oleh Dewi (2007) bahwa pada saat hujan vegetasi dengan tajuk yang rapat serta seresah yang tebal di permukaan tanah dapat melindungi tanah dari pukulan air hujan secara langsung sehingga melindungi tanah dari degradasi sifat fisik. Sebaliknya untuk lahan terbuka tanaman semusim, tanah lebih rentan terhadap pukulan air hujan sehingga agregat tanah menjadi rusak. Alih guna lahan menjadi tanaman semusim dapat menyebabkan terganggunya fauna permukaan tanah sebagai habitat maka kemungkinan bisa terjadi migrasi. Jadi berkurangnya diversitas dalam suatu ekosistem akan menurunkan kapasitas biologi dalam ekosistem untuk pengaturan fungsi internal karena fungsi biologi diganti masukan agro-kimia (Dewi, 2007).

\section{c. Kontribusi naungan pohon terhadap kepadatan cacing tanah}

Korelasi antara naungan pohon dengan kepadatan cacing tanah musim hujan menunjukkan hubungan positip dan cukup kuat $\left(\mathrm{r}=0,596^{* *}\right)$, hal ini dapat dijelaskan bahwa musim hujan akan meningkatkan kelembaban yang dibutuhkan cacing untuk menunjang kehidupannya dalam bereproduksi. Naungan pohon memberikan kontribusi sebanyak $71,5 \%$ terhadap kepadatan cacing musim hujan. hal ini dapat dijelaskan bahwa musim hujan akan meningkatkan kelembaban yang dibutuh-kan cacing untuk menunjang kehidupan-nya dalam bereproduksi sedang sumba-ngan naungan pohon pada pada kepada-tan cacing kemarau 52,2 \%. Hal ini bisa dipahami bahwa naungan pohon akan menggugurkan seresah sebagai makanan cacing pada berbagai lahan, dan sumbangan antara naungan pohon terhadap tebal seresah sebesar $46 \%$. Seresah akan dibawa masuk kedalam tanah dan dipotongpotong oleh cacing tanah untuk dimakan dan akhirnya akan dikeluarkan dalam bentuk kascing. Dilaporkan oleh Fraser, MP, et al.( 2003) dalam sebuah percobaan laboratorium bahwa interaksi antara cacing tanah, mikroba tanah dan akar tanaman mempengaruhi pemulihan dari tanah garapan yang terdegradasi.

\section{KESIMPULAN}

Penggunaan Lahan berpengaruh sangat nyata terhadap naungan pohon dan iklim mikro. Adanya perubahan dari hutan menjadi lahan pertanian akan mengakibatkan perubahan tutupan lahan sehingga berubah pula kondisi lingkungan seperti perubahan faktor iklim mikro.

Penggunaan Lahan berpengaruh nyata terhadap kepadatan populasi cacing tanah musim hujan dan berpengaruh sangat nyata terhadap kepadatan populasi cacing tanah musim kemarau. Namun untuk tanaman semusim masih bisa dipertahankan kepadatannya jika 
kondisi pemupukan organik dan penyiraman rutin dilakukan.

\section{DAFTAR PUSTAKA}

Dalgaard R.,T. Kelm, M. Wachendorf, F. Taube. 2003. Energy, Balance Comparison of Organic and Conventional Farming. In: OECD (ed) Organic agriculture: sustainability, markets and policies. CABI, Wallingford

Dewi,W.S. 2007. Dampak Alih Guna Hutan Menjadi Lahan Pertanian: Perubahan Diversitas Cacing Tanah dan Fungsinya Dalam Mempertahan-kan Pori Makro Tanah. (Disertasi tidak dipublikasikan: Program Pasca Sarjana Fakultas Pertanian Unibraw. Malang)

Edwards, C.H \&J.R.Lofty. 1977. Biology of Eathworm. London. Chapman and Hall. pp 77-221

Erniwati, 2008. Fauna Tanah Pada Stratifikasi Lapisan Tanah Bekas Penambangan Emas di Jampang, Sukabumi Selatan. Zoo Indonesia. 17(2): 85-95

Flessa, H., Ruser, R., Dörsch, P., Kampb, T., Jimenez, M.A., Munchb, J.C., and Beese, F. 2002. Integrated Evaluation of Greenhouse Gas Emissions (CO2, CH4, N2O) from Two Farming Systems in Southern Germany. Agric Ecosyst Environ 91:175-189

Foth, H.D., Adisoemarto, S. (alih Bahasa). 1994. Dasar-dasar Ilmu Tanah. Jakarta: Penerbit Erlangga

Fraser, M.P., Beare, M.H., Bulter, R.C., Kirk, T.H., and Piercy, J.E. 2003. Interactions between earthworm (Apprrectodea caliginosa), plants and crop residues for restoring properties of a degraded arable soil. Pedobiologia 47,870876.2003

Hale, C. M., Frelich, L. E., and Reich, P. B. 2006.Changes in Hardwood Forest Plant Communities in Response to European Earthworm Invasion. Ecology,vol.87,No.7 (jul.,2006), pp.1637-1649

Hairiah, K., Widianto, Suprayoga, D., Widodo, R. H., Purnomosidi, P., Rahayu, S., dan Noordwijk, V. 2004. Ketebalan Seresah Sebagai Indikator Daerah Aliran Sungai (DAS) Sehat. World Agroforestry Centre (ICRAF). Malang: Unibraw

Liu, Z. G. and Zou, X. M. 2002. Exotic earthworms accelerate Plant litter Decomposition in a Puerto Rican Pasture and a Wet Forest. Journal Ecologogical Application 12 (5).2007. pp.1406-1422

Nuril, H. B., Naiola, P., Sambas, E., Syarif., Sudiana, M., Rahayu, J.S, Suciatmih, Juhaeti, T., and Suharjono. 1999. Perubahan Bioekofisik Lahan Bekas Penambangan Emas di Jampang dan Metoda Oendekatannya Untuk Upaya Reklamasi. (Laporan Penelitian tidak dipublikasikan: Pengembangan dan pendayagunaan Potensi Wilayah tahun 2998/1999 Puslitbang Biologi LIPI)

Rachmawaty. 2004. Studi Keanekaragaman Mesofauna Tanah di Kawasan Hutan Wisata Alam Sibolangit. Universitas Sumatera Utara: Jurusan Kehutanan Program Studi Manajemen Hutan Fakultas Pertanian
Simek, M., Pizl, V. 2010. Soil CO2 flux affected by Aporrectodea caliginosa earthworm. Cent.Eur.J.Biol. 5(3).2010.364-370 DOI:10.2478/11535-010-0017-1

Sulistiyanto, Y., Rieley, J.O., dan Limin, S.H. 2005. Laju Dekomposisi Dan Pelepasan Hara Dari Serasah Pada Dua Sub-Tipe Hutan Rawa Gambut Di Kalimantan Tengah. Artikel. Jurnal Manajemen Hutan Tropika Vol. XI No. 2 : $1-14(2005)$

Sugiyarto. 2003. Konservasi Makrofauna Tanah dalam Agroforestry. Surakarta: LPPM. Bioteknologi dan Biodiversitas

Suin, N.M. 1997. Ekologi Hewan Tanah. Jakarta: Penerbit Bumi Aksara

Suprayoga, D., Hairiah, K., Wijayanto, N., Sunaryo dan Noordwijk, V. 2003. Peran Agroforestri Pada Skala Plot: Analisis Komponen Agroforestri Sebagai Kunci Keberhasilan Atau Kegagalan Pemanfaatan Lahan. World Agroforestry Centre (ICRAFT). Bogor

Yulipriyanto, H. 2010. Biologi Tanah dan Strategi Pengelolaannya. Yogyakarta: Graha Ilmu 